\title{
Assessment of Willingness to Pay as a Source of Financing for the Sustainable Development of Barobbob Watershed in Nueva Vizcaya, Philippines
}

\author{
Elizabeth T. Carig' ${ }^{1}$ Joel G. Carig ${ }^{2}$, Arvin P. Vallesteros ${ }^{3}$ \\ ${ }^{1}$ College of Agriculture, Forestry and Engineering, Quirino State University, Diffun, Philippines \\ ${ }^{2}$ Friends of the Environment for Development and Sustainability, Inc., Bayombong, Philippines \\ ${ }^{3}$ College of Forestry, Nueva Vizcaya State University, Bayombong, Philippines \\ Email: beth_frends@yahoo.com
}

Received 27 January 2016; accepted 11 March 2016; published 14 March 2016

Copyright (C) 2016 by authors and Scientific Research Publishing Inc.

This work is licensed under the Creative Commons Attribution International License (CC BY). http://creativecommons.org/licenses/by/4.0/

(c) (i) Open Access

\section{Abstract}

This study employed the Contingent Valuation Method to assess the willingness to pay of water users, as a source of financing for the sustainable development of Barobbob Watershed. The WTP study was conducted among 345 waters users in 19 barangays in the municipalities of Solano and Bayombong. Uncensored data revealed that $63.8 \%$ (58.84\% for the adjusted) of the respondents revealed willingness to pay for improved watershed management. The mean WTP amount, estimated through a logit model, Turnbull Distributor-Free Estimator and Lower Bound Estimate, is found to be PhP39.35, PhP27.80 and PhP25.90/month/household, respectively. Respondents WTP is influenced by bid amount, age, membership in environmental organization, experience with water-related problems, civil status, house ownership, and awareness on the concept of watershed. Respondents were willing to pay because they wanted a sustainable water supply for the present and future generations. A payment scheme is possible and it could provide a sustainable flow of fund, however, the willingness percentages still needed to be increased. Community education and public awareness (CEPA) campaign is necessary to enhance the water users' knowledge and understand about the importance and values of watersheds. Ultimately, WTP percentage and WTP amounts would increase.

\section{Keywords}

Willingness to Pay, Payment for Watershed Services, Watershed Management, Logit Model, Barobbob Watershed 


\section{Introduction}

Barobbob Watershed is a very important watershed in the province of Nueva Vizcaya, because it supports domestic and agriculture water needs of downstream communities in the municipalities of Bayombong and Solano. It also serves as resource base for upstream communities of barangay Masoc.

Water users of the Provincial Water Works System (PWWS), which tap water from Barobbob Watershed, have been experiencing water-related problems over the last few decades. Water shortage is very obvious during the summer season while during the rainy seasons, especially after heavy and continuous rain, water easily gets murky and cannot be used for household purposes. Water users need to wait for a day or two before water gets clear and can be used again.

Like any other watersheds in the country, there are numerous factors that affect the condition of Barobbob Watershed, to include among few, the establishment of road networks, residences, school buildings and other infrastructures, timber poaching, upland agriculture/slash-and-burn farming, and charcoal-making. Unfortunately, there are limited improvement done in the watershed to improve water quantity and quality.

The provincial government of Nueva Vizcaya has been allotting fund for Barobbob Watershed. However, the allotment is mainly used for reforestation and not enough to cover the development of individual farmlots. Because of inadequate funds, there is a need to explore other financing schemes to generate funds that may be used in the development of the watershed, and Payment for Watershed Services (PWS) is a viable option. PWS "seeks to establish new relationships between water users and upstream land managers" [1]. The involvement of watershed services "recipients" is very crucial because the money they contribute can be used in the development of the watershed area [2] "to synchronize land uses, improve livelihoods and land productivity without going against the concept of watershed management” [3].

This study assessed the willingness to pay of water users as a source of financing for the sustainable management of Barobbob Watershed. It also determined the potential amount of money water users who are willing to pay, the reasons for their willingness or non-willingness to pay and the factors that influenced their willingness to participate in the payment scheme.

\section{Materials and Method}

Barobbob Watershed is located in barangays of Magsaysay, Ipil Cuneg and Masoc within the municipality of Bayombong province of Nueva Vizcaya in the Philippines. It is situated approximately in between $16^{\circ} 29^{\prime} 29^{\prime \prime}$ and $16^{\circ} 31^{\prime} 03^{\prime \prime}$ north latitudes and $121^{\circ} 04^{\prime} 55^{\prime \prime}$ and $121^{\circ} 07^{\prime} 31^{\prime \prime}$ east longitudes (IRMP, 2015). It is bounded by the municipality of Ambaguio in the west, barangay Ipil Cuneg in the north, barangay Magsaysay in the south, and barangay La Torre South in the east. Refer to Figure 1 for the location map. It covers an approximate area of 869 hectares, divided into Upper Barobbob Watershed and Lower Barobbob Watershed, with 501 and 368 hectares area, respectively. From the total land area, 655.32 hectares falls within forestlands, while the remaining 213.68 hectares are classified as Alienable and Disposable (A \& D) lands. It is characterized by flat, sloping to rolling hills while some parts have rugged to steep terrain. From the total land area of the watershed, a little over $42 \%$ are within the $0 \%-18 \%$ slope, while the rest are almost evenly distributed in different categories. Around $18.90 \%$ of the watershed belongs to $50 \%$ - $100 \%$ slope category, mostly found along the ridge of the Caraballo mountain.

There are 28 water tributaries in the whole Barobbob Watershed, which all drain into the Barobbob creek. These tributaries all together, have an approximate length of 2.90 kilometers. Upper Barobbob has 18 creeks with a total length of 1.7 kilometers, while Lower Barobbob has 10 creeks with a length of 1.19 kilometers.

Respondents to the WTP study came from the 19 serviced barangays of the Provincial Water Works System (PWWS) located in the municipalities of Bayombong and Solano, Nueva Vizcaya. A total of 345 water users served as respondents to the study.

This study used the Contingent Valuation Method as the overall procedure in data gathering. A survey questionnaire was prepared following a series of activities. The Dichotomous Choice Method (DCM) or Referendum format was used in eliciting WTP. This method is very simple and familiar because the respondents only answered “yes" or "no" [4] to the CVM question.

The mathematical models and estimation used to determine willingness to pay is categorized into parametric and non-parametric models. Parametric approach, particularly the Logit model, was used in calculating the WTP of water users. Under the parametric approach, the characteristics of the respondents was integrated into the 


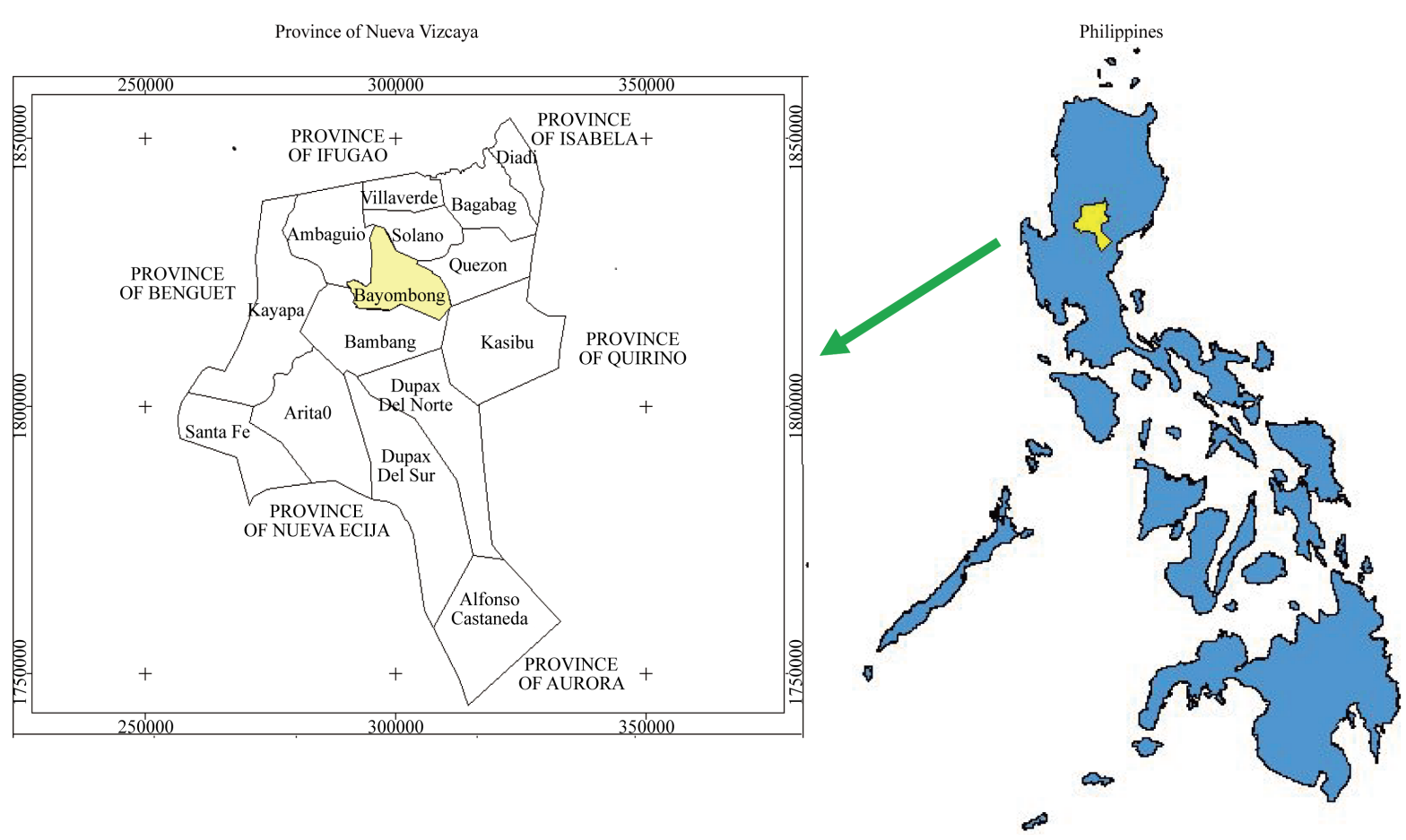

Figure 1. Location of Barobbob Watershed.

willingness to pay function (Haab and Mc Connel, 2002 as cited by [2]), to describe the preference tendencies of the respondents. It estimates the preference function and allowed the calculation of the willingness-to-pay amount given the estimated preference [2]. Based on Hanemann's formula, as cited by [5] and [6], the WTP for improved environmental quality using logit regression model is expressed as:

$$
\log \left[\frac{\operatorname{Pr}(\mathrm{WTP}=1)}{1-\operatorname{Pr}(\mathrm{WTP}=1)}\right]=\alpha+\beta_{1} X_{1}+\cdots+\beta_{2} X_{2}+\beta_{m} X_{m}+\beta_{n} A
$$

where: WTP $=1$ is equivalent to the "yes" vote.

$X_{1}, X_{2}, X_{3}, \cdots, X_{n}$ are the independent variables, and $A$ is the bid amount.

From the model, the mean WTP was calculated using the formula:

$$
\text { Mean }=\alpha / \beta
$$

where $\alpha$ is the constant plus the coefficients of the other variables multiplied by their respective mean values; $\beta$ is the coefficient of the bid amount variable.

Non-parametric approach used to calculate the mean and median WTP amount includes Turnbull Distribution-Free Estimator and the Lower Bound Estimate. Haab and McConnell (2002), as cited by [7], defined the parameters and relationships used in the Turnbull Distribution-Free Estimator are as follows:

\begin{tabular}{ccc}
\hline Parameter & Definition & Relation \\
\hline$B_{j}$ & Bid amount & \\
$M$ & Number of Bid amounts & \\
$N_{j}$ & Number of no responses (WTP $=0$ ) to bid $B_{j}$ & \\
$Y_{j}$ & Number of yes responses (WTP $=1$ ) to bid $B_{j}$ & $T_{j}=N_{j}+Y_{j}$ \\
$T_{j}$ & Total number of offered bid $B_{j}$ & $F_{j}=N_{j} / T_{j}$ \\
\hline$F_{j}$ & $\operatorname{Pr}(\mathrm{WTP} \leq 0)$ &
\end{tabular}


The method of calculating the Turnbull Distribution-Free Estimator are as follows:

1) For bids $\left(B_{j}\right)$ INDEXED $j=1, \cdots, M$, calculate $F_{j}=N_{j} /\left(N_{j}+Y_{j}\right)$ where $N_{j}$ is the number of "no" responses to $B_{j}$ and $Y_{j}$ is the number of "yes" responses to the same bid, and $T_{j}=N_{j}+Y_{j}$.

2) Beginning with $j=1$, compare $F_{j}$ and $F_{j+1}$.

3) If $F_{j+1}>F_{j}$, then continue.

4) If $F_{j+1}>F_{j}$, then pool cells $j$ and $j+1$ into one cell with boundaries $\left(B_{j}, B_{j+1}\right)$ and calculate

$F_{j}^{*}=\left\{N_{j}+N_{j}+1\right\} /\left\{T_{j}+T_{j+1}\right\}=N_{j}^{*} T_{j}^{*}$. That is eliminate bid $B_{j+1}$ and pool responses to bid $B_{j+1}$ with responses to bid $B_{j}$.

5) Continue until unit cells are pooled sufficiently to allow for a monotonically increasing sequence.

6) Set $F_{M+1}^{*}=1$.

Lower Bound Estimate is another method used in computing for the mean and median WTP. The procedures, as described by Bateman et al. (2002), as cited by [7] are as follows:

1) The percentage of "yes" responses for each given bid amount were computed, by dividing the number of "yes" responses with the total number of respondents who were offered each bid amount.

2) If the monotonic sequence of the probabilities is not satisfied, the pooling should be done using algorithm similar to the Turnbull estimation.

3) Compute for the estimates of the WTP probabilities that falls between bid amount $B_{j}$ and $B_{j+1}$.

4) Multiply each given bid amount $\left(B_{j}\right)$ by the possibility that WTP falls between it and the next highest price $\left(B_{j+1}\right)$ from Step 3.

5) Add the amounts from Step 3 over all bid amounts to get the approximate of the lower bound WTP, that is the mean WTP.

The Aggregate Willingness to Pay was determined using the computed mean WTP estimate. The monthly and yearly aggregate WTP amount was computed using the following formula:

$$
\text { Monthly Aggregate WTP }=\text { No. of households } \times \mathrm{M}(\mathrm{WTP}) \times \% \mathrm{HHPV}
$$

where:

No. of households $=$ Total number of water users registered with the PWWS/NAWASA (2,428 household users) $\mathrm{M}(\mathrm{WTP})=$ Willingness to pay estimate (computed mean)

\% HHPV = Percentage of households who voted "yes" (58.84\% for the adjusted data)

\section{Results and Discussion}

Table 1 presents the general profile of the respondents. The average age of the respondents is 44 years old. More than half of the respondents are female; married respondents are composed of 74 percent; and 47 percent of the respondents were able to reach or finished tertiary education. The average number of household members who are earning is 2. Majority of the households have monthly income of less than P20,000.00 and own the houses they reside in. Only less than 20 percent of the respondents are members of an environmental organization.

Table 1. Socio-economic profile of respondents.

\begin{tabular}{|c|c|c|}
\hline Indicator & Number & Percent \\
\hline Average Age & \multicolumn{2}{|l|}{44} \\
\hline Gender: Female & 180 & 52.2 \\
\hline Civil Status: Married & 255 & 73.90 \\
\hline Educational attainment: College and over & 162 & 47 \\
\hline Ave. number of household members earning income & \multicolumn{2}{|l|}{2} \\
\hline Number of household members: Small & 51 & 14.78 \\
\hline Total monthly income & $<\mathrm{PhP} 20,000.00$ & 73 \\
\hline Ownership of house: Owned & 280 & 81.2 \\
\hline Membership in environmental organization & 65 & 18.8 \\
\hline TOTAL NUMBER OF RESPONDENTS & \multicolumn{2}{|c|}{345} \\
\hline
\end{tabular}


Prior to determining the respondents' willingness to pay, several questions were asked from the respondents regarding their perception and awareness about the importance and values of watersheds. This is very important since perception and awareness regarding the matter definitely affects the willingness to pay of the respondents.

Majority (85.20\%) of the respondents knew that the PWWS water system draw water from Barobbob spring, while a little over $8 \%$ said it came from Luyang Reservoir. The rest of the respondents have varied answers, Magat river, deep well, and Matuno river. For respondents who did know the source of water, the research assistants informed them that Barobbob spring supplies water for the PWWS and Luyang reservoir is only a temporary water storage area and not the main water source.

Almost $80 \%$ of the total respondents knew the concept of watershed and that Barobbob is a watershed area. However, a smaller percentage knew that watersheds are considered water protection areas because of their critical role as water source. Majority of the respondents are not familiar with the Barobbob Co-Management Project (BCMP) and that Barobbob is also a water source protection area. The result confirmed the findings of [8], where majority of water users need to be educated about the co-management project in Barobbob and its status as a water source protection area (see Table 2).

The uncensored vote revealed that $63.8 \%$ of the total respondents are willing to pay at various bid levels, while $32.30 \%$ responded "no" to the WTP question (Table 3). Biases were eliminated by asking certainty question to the respondents. Those who voted "not sure" and "completely not sure" to the follow-up question were considered as "no" responses. As a result, the WTP percentage declined from $63.80 \%$ to $58.84 \%$ while the "no" responses increased from $32.30 \%$ to $41.16 \%$. The trend on declining percentage of yes votes with increasing bid amount in the uncensored and adjusted votes remained the same after adjustments were made. This result conforms to the Utility Theory and other similar studies like that of [2] [5] [6] [9], where they concluded that willingness to pay is affected by the price of the goods. The higher the price of a certain good, the lesser is the willingness of consumers to pay for it, and vice versa.

Table 4 provides summary of the computed WTP estimates using parametric and non-parametric models. The Turnbull estimator yielded a monthly mean WTP of P27.80 and median WTP ranging from P30-50. For the Lower Bound Estimate, the mean WTP was estimated to be equal to $\mathrm{P} 25.90$ while the median is $\mathrm{P} 39.00$. The Logit Model resulted in mean WTP amount of P39.35 and median WTP of P47.16.

Using the above figures, the monthly aggregate WTP amount is estimated to be $\mathrm{P39,700.00} \mathrm{(Turnbull} \mathrm{Esti-}$ mator), $\mathrm{P} 37,000.00$ (Lower Bound Estimate) and $\mathrm{P} 56,216.80$ (Logit) and the aggregate yearly amount ranges from $\mathrm{P} 444,000.00$ to $\mathrm{P} 670,000.00$.

Table 2. Knowledge of respondents about watershed and related concept.

\begin{tabular}{ccccc}
\hline & \multicolumn{5}{c}{ Response } \\
\cline { 2 - 5 } Statement & Aware & $\%$ & Not Aware & $\%$ \\
\hline Watershed concept & 274 & 79.42 & 71 & 20.58 \\
Barobbob as a watershed & 273 & 79.13 & 72 & 20.83 \\
Watershed as water source protection area & 187 & 54.20 & 158 & 45.80 \\
Barobbob Co-management project (BCMP) & 108 & 31.30 & 237 & 68.70 \\
BCMP as water source protection area & 92 & 26.70 & 253 & 73.70 \\
\hline
\end{tabular}

Table 3. Uncensored and adjusted vote to the willingness to pay question.

\begin{tabular}{ccccc}
\hline \multirow{2}{*}{ Response to the WTP question } & \multicolumn{2}{c}{ Uncensored Vote } & \multicolumn{2}{c}{ Adjusted Vote } \\
\cline { 2 - 5 } & Frequency & Percent & Frequency & Percent \\
\hline Yes & 229 & 63.8 & 203 & 58.84 \\
No & 116 & 32.3 & 142 & 41.16 \\
Total & $\mathbf{3 4 5}$ & $\mathbf{1 0 0}$ & $\mathbf{3 4 5}$ & $\mathbf{1 0 0}$ \\
\hline
\end{tabular}


From a total of 19 socio-economic and awareness variables tested, only seven variables showed significant effect on WTP (Table 5). These variables include bid amount, age, membership in environmental organization, experience with water-related problems, civil status, house ownership and awareness on the concept of watershed. The Hosmer and Lemeshow Test (H-L) statistic revealed that the signs of the coefficients of variables included in the model are all in the expected directions.

The independent variable of bid amount was found to have significant but negative relationship with WTP. This means that respondents will become less willing to pay for improved watershed management as the bid amount increases. This finding coincides with the finding of [10] [11], wherein the number of consumers who are willing to pay decline with an increase in bid amount.

Another indicator with significant but negative relationship with WTP is age. Younger respondents have a higher probability of willingness to pay than the older respondents. The possible reason for this result is the exposure of younger generations with environmental problems and environment-related disasters, which were seldom experienced by older respondents during their younger years. However, this finding is surprising compared to the result of other related studies like that of [12]-[15], all found that older people have higher WTP than the younger generation. Accordingly, older people are more financially stable and want to leave a legacy to conserve forest resources [14]. Therefore, their willingness to pay is higher.

Another variable with significant and positive coefficient with WTP is civil status. The result showed that married respondents have higher WTP than the single respondents. The possible reason for this finding may be attributed to the concern of married respondents with their family members. Basically, married respondents are concerned with the welfare of their families and would always want the best for them, even if it meant paying for additional amount just to ensure that they will have sustainable supply of water in their household. This finding conforms to the finding of [8] where civil status was found to be an important factor for WTP.

House ownership has significant and positive influence on WTP. Those who own their house are more likely be willing to pay than those who are just renting or staying with their relatives. Ownership of house is a proof of the capacity to pay of the respondents.

Membership in environmental organization also has significant effect on WTP. Respondents who are members of environmental organization are more willing to pay for improved watershed than non-members. Members of environmental organizations are usually provided with seminars and trainings, information and educational campaigns on environmental management. Their exposure to various projects and activities is of the reasons why they are willing to pay to ensure that their resource base is properly protected.

Table 4. Parametric and non-parametric WTP estimates.

\begin{tabular}{ccc}
\hline Model & Mean WTP & Median \\
\hline Turnbull estimator & P 27.80 & P $30.00-50.00$ \\
Lower Bound Estimate & P 25.90 & P 39.00 \\
Logit model & P 39.35 & P 47.00
\end{tabular}

Table 5. Siginificant factors affecting ewillingness to pay.

\begin{tabular}{ccc}
\hline Variables with significant factor & Coefficient & Probability value \\
Bid Amount & $-.517^{*}$ & .000 \\
Age & $-.037^{*}$ & .005 \\
Civil Status & $1.275^{*}$ & .004 \\
House Ownership & $2.193^{*}$ & .000 \\
Membership in environmental organization \\
Experience with water-related problems \\
Knowledge on the concept of watershed
\end{tabular}

${ }^{*} p<0.05$ (significant at 5\%). 
The last socio-economic variable with significant effect on WTP is experience with water-related problems. Respondents who have experienced water interruptions and health-related diseases are more willing to pay than respondents who have not experienced any problem. The main reason is that they do not want to experience the same problem anymore that is why they are willing to pay for the management and protection of Barobbob Watershed.

The only level of awareness variable with significant effect on WTP is awareness on the concept of watershed. Respondents who know the concept of watershed and its important role in ensuring sustainable flow of water are more willing to pay than those who do not know the concept. These respondents know that degraded watersheds would not be able to function properly and would not be able to provide the services expected of watersheds. This is the reason why they are willing to pay additional amount for improved watershed management.

Respondents who responded "no" to the WTP question were asked for the reasons behind their responses. Half of the respondents said that the government should be responsible in ensuring the management and protection of Barobbob. Others said that they are already paying their monthly bills, therefore, the provincial government through the PWWS should allocate certain amount from the collected water users fee for individual farm lot development. Another 25\% of those who said "no", explained that paying additional amount will not improve Barobbob Watershed and a little less than $20 \%$ said they cannot afford to pay additional amount from what they are currently paying. Other reasons include the following: Protection of Barobbob Watershed is not worth doing, water reliability is not important to me, and improved watershed will not result to more reliable water supply.

On the other hand, respondents who responded positively to the WTP question were also asked why they are willing to pay additional amount for the management and protection of Barobbob Watershed. Six reasons cropped up, but the three major reasons with the highest percentage include the following: respondents want a more reliable water supply (37.12\%), respondents want the future generation to have a reliable water supply too (25.76\%), and for Barobbob to continue producing watershed services (24.89\%).

\section{Conclusions}

There is evidence that a payment scheme is possible for Barobbob Watershed as shown in the WTP percentage, $63.80 \%$ (uncensored) and 58.84\% (adjusted). The computed aggregate mean and median WTP shows that the proposed scheme can provide a sustained flow of funding for Barobbob Watershed. However, the WTP percentage suggests that a significant number of water users are not willing to participate in the payment scheme because of various reasons.

The provincial government, being the Memorandum of Agreement (MOA) holder for almost half of Barobbob Watershed, and the municipal government of Bayombong, having jurisdiction over the remaining open access areas in the watershed, may form a technical working group who will work on the updating of the management and development plan of Barobbob Watershed, giving special provisions on the conduct of community education and public awareness campaign, forest restoration projects, organizational development and management and capability-building, among others. While the plan is not yet revisited, the provincial government through the Environment and Natural Resources Office and PWWS, may intensify CEPA activities focusing on the importance and values of watershed to help water users make informed decisions. The conduct of this activity will also increase the chances of getting higher WTP responses. Higher WTP percentage will also increase the amount that may be generated from a PWS scheme. If PWS is to be institutionalized, public hearings and consultation may be undertaken before bid amounts are finalized, since the estimates from this study are only contingent. Another study on the possible institutional mechanism for the operation of a PWS scheme may also be conducted.

\section{Acknowledgements}

Special thanks to Quirino State University headed by Dr. Samuel O. Benigno, University President, Dr. Fredisminda M. Dolojan, Director for Research and Development and to the members of the Faculty and Staff Development Committee, to the Commission on Higher Education (CHED), the Philippine Tropical Forest Conservation Foundation (PTFCF), Eco Peace Leadership Center-Yuhan Kimberly and Ford Foundation International Fellowship Alumni Awards for their assistance. 


\section{References}

[1] Bond, I. (2007) Payments for Watershed Service: A Review of Literature: Report Contributing to the Scoping Exercise Managed by IIED to Help Develop a DFID Research Programme on Water Ecosystems and Poverty Reduction under Climate Change. International Institute for Environment and Development, Rep. N.p.

[2] Amponin, J.A., Bennagen, M.E., Hess, S. and Dela Cruz, J.D. (2007) Willingness to Pay for Watershed Protection by Domestic Water Users in Tuguegarao City, Philippines. http://www.premonline.nl/archive/5/doc/PREM\%20WP\%2007-06.pdf

[3] IRMP (2005) Integrated Resources Management Plan for Magat Subwatershed, Bayombong, Nueva Vizcaya.

[4] Ndebele, T. (2009) Economic Non-Market Valuation Theory: Theory and Application to Ecosystem and Ecosystem Services. A Case Study of the Restoration and Preservation of the Pekapeka Swamp: An application of Contingent Valuation Method in Measuring and Preserving Ecosystem Services in an Impaired Wetland. Unpublished Thesis. Massey University, Switzerland.

[5] Celeste, N.E. (2009) Estimating the Benefits of Watershed Protection for Sustainable Water Supply in Sibalom Natural Park Sibalom, Antique. Master's Thesis, Visayas State University, Visca.

[6] Calderon, M.M., Camacho, L.D., Carandang, M.G., Dizon, J.T., Rebugio, L. and Tolentino, N.L. (2005) A Water User Fee for Households in Metro Manila, Philippines. A Research Report. No. 2005-RR2, Economy and Environment Program for Southeast Asia.

[7] Carandang, M.G., Calderon, M.M., Camacho, L.D. and Dizon, J.T. (2008) Parametric and Non-Parametric Models to Estimate Households' Willingness to Pay for Improved Management of Watershed. Journal of Environmental Science and Management, 11, 68-78.

[8] Carig, J.G. (2015) Water Users’ Willingness to Pay for the Management and Protection of Barobbob Watershed. Master's Thesis, Nueva Vizcaya State University, Bayombong.

[9] Hashimoto, K. (2008) Study on Willingness to Participate in the Payment for Environmental Services Scheme in the Mara Basin. Florida International University, Miami.

[10] Ureta, J.C.P., Lasco, R.D., Sajise, A.J. and Calderon, M.M. (2014) Oroquieta City Households' Willingness to Pay for Coastal Biodiversity Conservation. Journal of Sustainable Development, 7, 82-91.

[11] Tang, Z., Nan, Z. and Liu, J. (2012) The Willingness to Pay for Irrigation Water: A Case Study in Northwest China. Global Nest Journal, 15, 76-84.

[12] Ndetewio, P.I., Mwajake, A.G., Mujwahuzi, M. and Ngana, J. (2013) Factors Influencing Willingness to Pay for Watershed Services in Lower Moshi, Pangani Basin, Tanzania. International Journal of Agriculture \& Environment, 2.

[13] Zhaoyi, S., Che, Y., Yang, K. and Jiang, Y. (2012) Assessing Local Communities’ Willingness to Pay for River Network Protection: A Contingent Valuation Study of Shanghai, China. International Journal of Environmental Research and Public Health, 9, 3866-3882. http://dx.doi.org/10.3390/ijerph9113866

[14] Youe, A. and Pabuayon, I.M. (2011) Willingness to Pay for the Conservation of Flooded Forest in the Tonle Sap Biosphere Reserve, Cambodia. International Journal of Environmental and Rural Development, 2-2, 1-5.

[15] Akter, S. (2006) Farmers Willingness to Pay for Irrigation Water Under Government Managed Small Scale Irrigation Projects in Bangladesh. Journal of Bangladesh Studies, 9, 21-31. 